\title{
IEVADS
}

\section{GUNDARS MEŽINSKIS} Silikātu materiālu institūts, Rīgas Tehniskā universitāte, Rīga, Latvija

Pagājušā gada 1. oktobrī apritēja 70 gadi, kopš dibināta Rīgas Tehniskās universitātes (RTU) Silikātu tehnologijas katedra. Katedras 50 gadu jubilejas reizē RTU izdevniecība publicēja monogrāfiju (brošūru), kurā tika sniegts pārskats par Silikātu materiālu institūtā (SMI) paveikto mācību un zinātniskā darbā no 2002. līdz 2007. gadam [1]. Savukārt 2013. gadā RTU Materiālzinātnes un lietišķās ķīmijas fakultātes 150 gadu jubilejas priekšvakarā tika publicēta kolektīvā monogrāfija, kurā SMI veltītajā nodaḷā îsumā apskatīta silikātu tehnoloǵijas kā studiju priekšmeta attīstība, kā arī katedras būtiskākie sasniegumi un notikušās izmaiṇas kopš pēdējiem gadiem pirms Latvijas neatkarības atgūšanas, smagā desmitgade pēc tam, kā arī dots ieskats institūta attīstībā lìdz pat 2013. gadam [2].

Materiālzinātnes un lietišḳās k,īmijas zinātniskā žurnāla sējuma Nr. 35 izdevumā apkopoti raksti latviešu valodā, kuru mērķauditorija ir fakultātē studējošie un Latvijas rūpniecības uzñēmumu speciālisti. Šajos rakstos mēgināts aprakstīt gan ilgāku pētījumu rezultātus, gan pēdējo gadu nozīmīgākos sasniegumus jaunu tehnologiju un materiālu izstrādē.

Šì žurnāla izdevuma pirmā raksta mērksis - sniegt ieskatu Latvijas Republikas uzñēmumos, kas ir potenciālās darba vietas studentiem un absolventiem un kas savos ražošanas procesos izmanto silikātu, augsttemperatūras materiālu vai neorganisko nanomateriālu tehnoloǵijas. Rakstā apkopotas un analizētas būtiskākās izmaiṇas pēdējās desmitgades laikā RTU Silikātu, augsttemperatūras un neorganisko nanomateriālu tehnoloǵijas (SANNT) katedrā un SMI.

Rakstā "Celtniecības keramika, keramzīts un keramiski sorbenti" sniegts apraksts pētījumiem, kas veikti keramiskajiem materiāliem un materiāliem uz neorganisko javu saistvielu bāzes, analizējot un salīdzinot šo materiālu fizikālās un mehāniskās īpašības. Galvenā uzmanība pievērsta keramzīta un keramisko sorbentu iegūšanai no Latvijas māliem ar dažādu k̦īmisko un mineraloǵisko sastāvu.

Risinot ekologiska rakstura problēmas, rakstā "Latvijas minerālās izejvielas eko-keramikas izstrādei" aprakstītas iespējas izmantot Latvijas minerālās izejvielas par bāzi vai piedevu ekoloǵiski tīrāku 
keramikas materiālu izstrādei ar dažādiem pielietošanas aspektiem. Parādīta iespēja iegūt siltumizolējošu materiālu, izmantojot geopolimēru metodi.

Minerālo saistvielu pētījumi tradicionāli ir otrais pētījumu virziens SMI. Rakstā "Minerālo saistvielu pētījumi Silikātu materiālu institūtā" parādīti pēdējās desmitgades pētījumi minerālo saistvielu jomā, sniedzot ziṇas par dažādu aktīvo k̦īmisko piedevu ietekmi un dažādu rūpniecisko blakus produktu (pelnu kā pucolānu) piedevu ietekme uz betona īpašībām.

Trešais pētījumu virziens ir saistīts ar sadarbību ar AS Valmieras stikla šksiedra daudzu gadu desmitu garumā. Pētītas iespējas izmantot jaunas izejvielas stikla škjiedras ražošanā, īpašu uzmanību pievēršot Latvijas devona un juras perioda smiltīm. Veikti defektu pētījumi E-tipa un augsta $\mathrm{SiO}_{2}$ satura stikla šķiedrām, kā arī pētījumi par izejvielu k̦īmiskā sastāva dispersitātes un tehnologísko parametru ietekmi uz šķiedru kvalitāti.

Kopš 1984. gada SMI Akmens materiālu konservācijas un restaurācijas centrā tiek veikti pētījumi par Latvijas kultūrvēsturisko ēku akmens materiālu koroziju. Rakstā "Vēsturisko mūrjavu ilgmūžības nodrošināšana Latvijas senatnes būvēs" ir aprakstīti korozijas procesi vēsturiskās ēkās, to izpētes metodika un mūrjavu ilgmūžības nodrošināšanas pamatprincipi. Savukārt otrajā šī centra speciālistu rakstā sniegts ieskats mūrējuma korozijas mehānismos. Detalizētāka informācija sniegta par dzelzsbetona koroziju.

Rakstā "Augsti poraina oksīdu keramika” sniegtas ziṇas par materiālu izstrādi izmantošanai augsttemperatūras siltumizolācijā dažādām augsttemperatūras siltuma ierīcēm, kā arī karstumizturīgos filtros. Sniegts ieskats pētījumiem $\mathrm{ZrO}_{2}, \mathrm{TiO}_{2}$ un mullīta-korunda augsti porainas augsttemperatūras keramikas izstrādē.

Veikti pētījumi blīvas augsttemperatūras mullīta- $\mathrm{ZrO}_{2}$ keramikas izstrādē, izmantojot silīcija nitrīda un SiAlON nanopulveru piedevas. Keramikas saḳepināšanai izmantota gan tradicionālā metode, gan plazmas dzirksteḷizlādes saķepināšanas process.

Pēdējie divi sējuma raksti saistīti ar mūsdienās populārāko nanomateriālu sintēzes metodi - sola-gēla tehnologiju.

Rakstā "Sola-gēla pārklājums uz emaljēta legētā tērauda" aprakstītas jauna materiāla un tehnologijas izstrādes stadijas saules enerǵijas kolektoriem. Materiāla pamatā ir nerūsējošā tērauda caurulveida izstrādājums, kuram uzklāts stiklkristālisks emaljas pārklājums, kas savukārt pārklāts ar sola-gēla pārklājumu. Iegūtais kompozìtmateriāls spēj izturēt $600^{\circ} \mathrm{C}$ vismaz 250 dienas.

Pēdējais sējuma raksts veltīts kopš 2015. gada attīstītam jaunam pētījumu virzienam - pašattīrošo audumu ieguvei. Pašattīrošiem 
audumiem piemīt spēja ārēju vides faktoru iedarbībā atbrīvot savu virsmu no dažādiem piesārṇojumiem. Iegūti ar anatāza nanodaḷiņām pārklāti kokvilnas audumi, kas UV gaismā uzrādīja fotokatalītisku aktivitāti. Jāatzīmē, ka nanodaḷiṇas tika sintezētas ar zemtemperatūras solagēla metodi.

\section{LITERATŪRAS SARAKSTS}

[1] G. Mežinskis un R. Švinka, Silikātu tehnologijas katedrai 60: pārskats par mācību un zinātnisko darbu 2002. - 2007. Rīga, Latvija: RTU Izdevniecība, 2007.

[2] G. Mežinskis un R. Švinka, "Silikātu materiālu institūts," no Rīgas Tehniskās universitātes Materiālzinātnes un lietišksās ksīmijas fakultātei - 150. Rīga, Latvija: RTU Izdevniecība, 2013, 293.-318. lpp.

Gundars Mežinskis, Dr. habil. sc. ing. (1998. g.), Rīgas Tehniskās universitātes profesors (2000. g.), RTU Silikātu materiālu institūta direktors (2000. g.) un Silikātu, augsttemperatūras un neorganisko nanomateriālu tehnologijas katedras vadītājs (2007. g.). Viṇš ir 248 zinātnisko publikāciju autors, kā arī 5 inženiera diplomdarbu, 10 bakalaura, 30 maǵistra darbu un 6 doktora disertāciju zinātniskais vadītājs.

E-pasts: gundars.mezinskis@rtu.lv

ORCID: 0000-0002-6030-4247 